\title{
A REVIEW OF ${ }^{14} \mathrm{C}$ WASTE ARISING FROM THE NUCLEAR INDUSTRY IN THE UNITED KINGDOM
}

\author{
NIALL MCNAMARA, MARTIN MCCARTNEY
}

Scottish Universities Research and Reactor Centre, Scottish Enterprise Technology Park

East Kilbride, G75 0QU, United Kingdom

and

\section{E. M. SCOTT}

Department of Statistics, University of Glasgow, University Gardens, Glasgow, G12 8QW

United Kingdom

\begin{abstract}
We report on a review of ${ }^{14} \mathrm{C}$ production and release from the nuclear industry in the United Kingdom (UK). Using earlier predictions (Bush, White and Smith 1984) it is estimated that a total of $1764 \mathrm{TBq}$ of ${ }^{14} \mathrm{C}$ would have been produced in UK graphite-moderated reactors up to the end of 1995 , and $135 \mathrm{TBq}$ of this total would have been released. Release rates, based on reported discharges, of 5.1 and $0.93 \mathrm{TBq} \mathrm{GW}(\mathrm{e}) \mathrm{a}^{-1}$ have been derived for Magnox reactors and Advanced Gas Cooled Reactors (AGRs), respectively. Using these new figures, cumulative discharges of ${ }^{14} \mathrm{C}$ up to 1995 from reactors have been estimated at $531 \mathrm{TBq}$. The combination of these reactor discharges and the reported discharges from Sellafield (388 $\mathrm{TBq}$ ) and Amersham (52 TBq) suggest a total cumulative release of $971 \mathrm{TBq}$ of ${ }^{14} \mathrm{C}$ up to the end of 1995.
\end{abstract}

\section{INTRODUCTION}

The production and subsequent release of ${ }^{14} \mathrm{C}$ contributes a significant fraction of the radiation dose delivered to both local and global populations from the nuclear industry (Kelly et al. 1975; Killough and Rowher 1978; McCartney, Baxter and Scott 1988a,b; UNSCEAR 1993). The UK is a very important source of ${ }^{14} \mathrm{C}$ for a number of reasons: first, the Sellafield nuclear fuel reprocessing plant has been identified by UNSCEAR (1993) as the largest single contributor of ${ }^{14} \mathrm{C}$ discharges to the global environment; second, ${ }^{14} \mathrm{C}$ production and release rates for the graphite-moderated nuclear reactors, which are the mainstay of the UK nuclear power program, are relatively high, and finally, significant quantities of ${ }^{14} \mathrm{C}$ tracer compounds are produced in the UK for use in medicine, research and industry.

In recent years, the amount of ${ }^{14} \mathrm{C}$ discharge information published in the UK has greatly increased in response to new authorizations requiring the monitoring and reporting of these data. However, great uncertainty remains regarding the historical releases of ${ }^{14} \mathrm{C}$ within the UK. The aim of this study, therefore, is to estimate the magnitude of the historical discharges of ${ }^{14} \mathrm{C}$ from the UK nuclear industry, making use of reported discharges when possible and, where necessary, estimating release rates on the basis of the most recent data available.

\section{${ }^{14} \mathrm{C}$ AND THE UK NUCLEAR INDUSTRY}

\section{Nuclear Reactors}

The production of ${ }^{14} \mathrm{C}$ in nuclear reactors results mainly from the neutron activation of ${ }^{13} \mathrm{C},{ }^{14} \mathrm{~N}$ and ${ }^{17} \mathrm{O}$ present in the fuel, moderator, coolant and core construction materials. The relative importance of each production route varies according to the individual reactor design. Up to 1995, ca. $99 \%$ of the nuclear power generated in the UK derived from graphite-moderated reactors, either Magnox or AGR reactors. The most significant production routes for these types of reactors are via ${ }^{14} \mathrm{~N}(\mathrm{n}, \mathrm{p}){ }^{14} \mathrm{C}$ and ${ }^{13} \mathrm{C}(\mathrm{n}, \gamma){ }^{14} \mathrm{C}$ reactions in the fuel, moderator and, to a lesser extent, coolant. Most recent publi- 
cations concerned with ${ }^{14} \mathrm{C}$ production in graphite-moderated reactors can be traced back to three studies (Kelly et al. 1975; Bonka 1980; Bush, Smith and White 1984). The latest estimates published in the open literature, by Bush, White and Smith (1984), were based on UK-designed AGR and Magnox reactors and are shown in Table 1.

TABLE $1 .{ }^{14} \mathrm{C}$ Production Rates in Magnox Reactor and AGR Compo-

\begin{tabular}{lcc} 
nents (TBq GW(e) $\left.\mathrm{a}^{-1}\right)$. (After Bush, White and Smith (1984)) \\
\hline Component & Magnox & AGR \\
\hline Fuel & 3.74 & 0.3 \\
Cladding & 0.30 & 1.81 \\
Coolant & 0.41 & 0.22 \\
Graphite & 9.55 & 5.67 \\
Total & 14.00 & $\mathbf{8 . 0}$ \\
\hline
\end{tabular}

Magnox reactors have a higher ${ }^{14} \mathrm{C}$ production rate than AGRs, which is largely attributable to the higher production in Magnox fuels and moderators. ${ }^{14} \mathrm{C}$ production rates in Magnox reactors and AGRs exceed those in the more common light water reactors, $1-4 \mathrm{TBq}$ GW(e) $\mathrm{a}^{-1}$ (Davis 1979) but are lower than those observed in heavy water reactors, 16-22 TBq GW(e)a ${ }^{-1}$ (NCRP 1985; Joshi, Ramamirtham and Soman 1987). Using these ${ }^{14} \mathrm{C}$ production estimates and reactor electricity production figures (IAEA 1996), it is possible to calculate the total production of ${ }^{14} \mathrm{C}$ in UK graphitemoderated reactors up to 1995 . The ${ }^{14} \mathrm{C}$ production estimates of Bush, White and Smith (1984) give a total production of $1764 \mathrm{TBq}, 1316 \mathrm{TBq}$ from Magnox reactors and $448 \mathrm{TBq}$ from AGRs. Although several other reactor types have operated in the UK, theoretical calculations suggest that their contribution to the total production of ${ }^{14} \mathrm{C}$ in $\mathrm{UK}$ reactors is rather insignificant (i.e., $<1 \%$ of the estimated total).

Discharges at graphite-moderated reactor sites are usually the result of leakage of ${ }^{14} \mathrm{C}$ produced in the coolant or transferred to the coolant from the moderator (Bonka 1980; Bush, White and Smith 1984). Short-term releases at a higher level also occur during reactor shutdown and start-up. The ${ }^{14} \mathrm{C}$ discharge rates calculated by Bush, White and Smith (1984) are presented in Table 2. In both cases, ${ }^{14} \mathrm{C}$ release rates are approximately an order of magnitude less than the ${ }^{14} \mathrm{C}$ production rates. It is also interesting to note that graphite corrosion is calculated to contribute more ${ }^{14} \mathrm{C}$ to the gaseous discharges than that produced in the coolant.

TABLE 2. ${ }^{14} \mathrm{C}$ Release Rates in Magnox Reactors and AGRs (TBq GW(e) $\left.\mathrm{a}^{-1}\right)$. (After Bush, White and Smith (1984))

\begin{tabular}{lcc}
\hline Source & Magnox & AGR \\
\hline Coolant & 0.41 & 0.22 \\
Graphite corrosion & 0.70 & 0.33 \\
Total & 1.11 & 0.55 \\
\hline
\end{tabular}

Due to new authorizations requiring the monitoring and reporting of ${ }^{14} \mathrm{C}$ discharges from many UK reactors, the opportunity arose to test these theoretical release estimates with real discharge data (Hurst and Thomas 1992; Thomas 1993, 1994, 1996; Scottish Nuclear 1996, 1997; MAFF 1996). Reported discharges are based on measured ${ }^{14} \mathrm{C}$ activities in coolant samples and coolant leakage rates. Electricity production estimates were obtained from IAEA (1996). In Figure 1, the reported discharges in 1994 are compared with those predicted by Bush, White and Smith (1984). In all but 


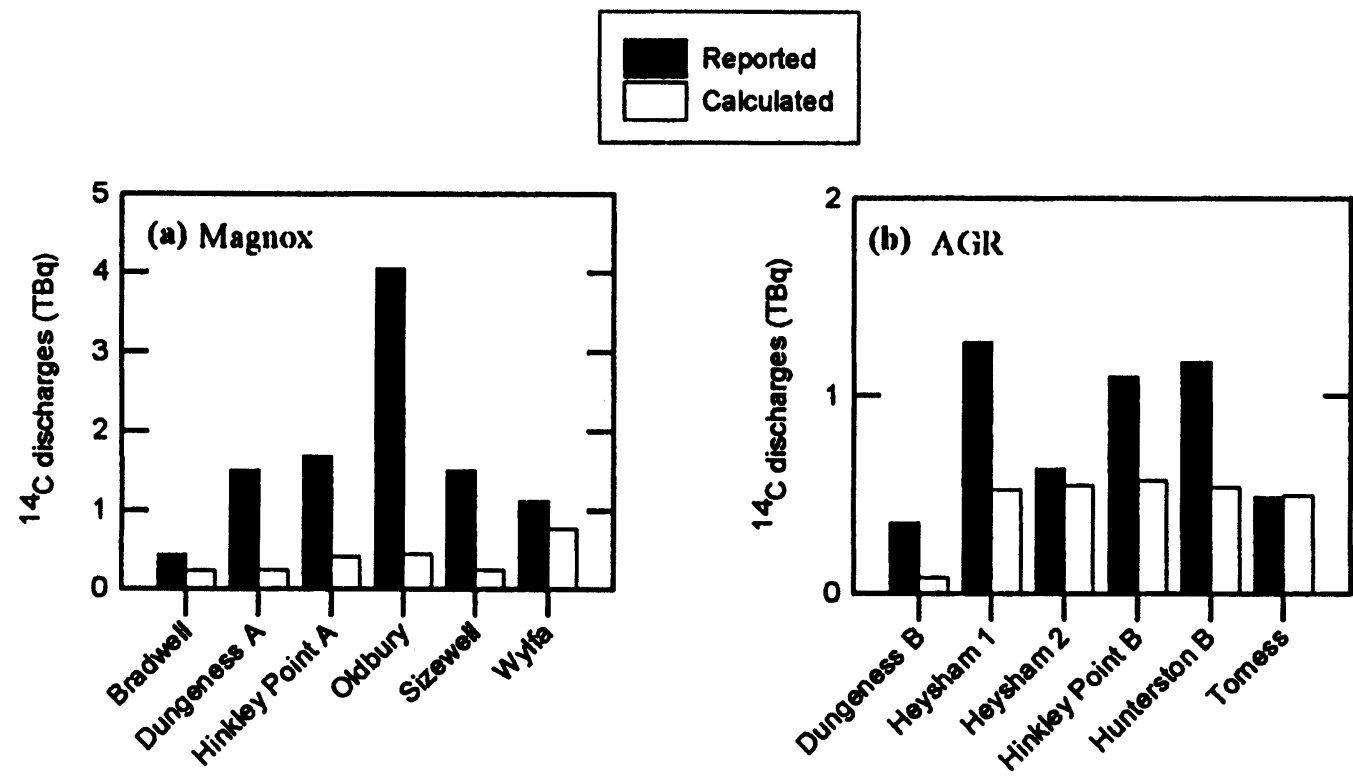

Fig. 1. Comparison of reported ${ }^{14} \mathrm{C}$ discharges for 1994 with the theoretical estimates of Bush, White and Smith (1984) for (a) Magnox reactors and (b) AGRs

one of the twelve reactors for which information is available, the predicted discharges are lower than the reported discharges. The difference is notably greater for Magnox reactors.

Considering the discrepancy between the reported and calculated discharges, new release rates have been determined, based upon all available discharge data for the period up to and including 1995. These data sets ranged from 2 to 8 years in length. The results are presented in Figure 2. Certain sites had very consistent discharge rates from year to year (e.g., Wylfa, 1.51-1.61 TBq GW(e) $\mathrm{a}^{-1}$ over the period 1990-1995) while others had quite large annual variations. Nevertheless, the average discharge rate obtained for each reactor was always in excess of the value predicted by Bush, White and Smith (1984). The average release rates for each reactor are tabulated in Tables $3 a$ and $3 b$.

The ${ }^{14} \mathrm{C}$ release rates obtained for both reactor types, averaged over all sites, are in excess of the values predicted by Bush, White and Smith (1984). For Magnox reactors, the measured release rate (5.1 TBq GW(e) $\left.\mathrm{a}^{-1}\right)$ is 4.6 times higher than the predicted value of $1.1 \mathrm{TBq} G W(\mathrm{e}) \mathrm{a}^{-1}$; for AGRs the measured rate $\left(0.93 \mathrm{TBq} \mathrm{GW}(\mathrm{e}) \mathrm{a}^{-1}\right)$ is almost twice the predicted value of $0.55 \mathrm{TBq} \mathrm{GW}(\mathrm{e}) \mathrm{a}^{-1}$. The range of ${ }^{14} \mathrm{C}$ release rates for Magnox reactors $\left(1.6-9.4 \mathrm{TBq} \mathrm{GW}(\mathrm{e}) \mathrm{a}^{-1}\right)$ is also far greater than for AGRs $\left(0.63-1.23 \mathrm{TBq} \mathrm{GW}(\mathrm{e}) \mathrm{a}^{-1}\right)$ and is probably a reflection of the greater variability in designs of the former.

Figure 3 shows the temporal variations in the annual ${ }^{14} \mathrm{C}$ discharges from Magnox reactors and AGRs over the period 1956-1995, based on the release estimates determined in this study. Discharge rates have been rather constant over the last two decades, varying between 15 and $20 \mathrm{TBq} \mathrm{a}^{-1}$, despite the fact that the amount of electricity generated annually by graphite-moderated reactors increased from $c a .3$ to $9 \mathrm{GW}(\mathrm{e})$ a. The increased electricity production over this time period resulted from the commissioning of the AGRs, which, as is demonstrated in Figures $2 a$ and $2 b$, have far lower ${ }^{14} \mathrm{C}$ release rates than the Magnox reactors that they were partially replacing. The first of the AGRs came on line in 1976 and by 1995 were generating ca. $6 \mathrm{GW}(\mathrm{e})$ a of electricity per year. The data pre- 

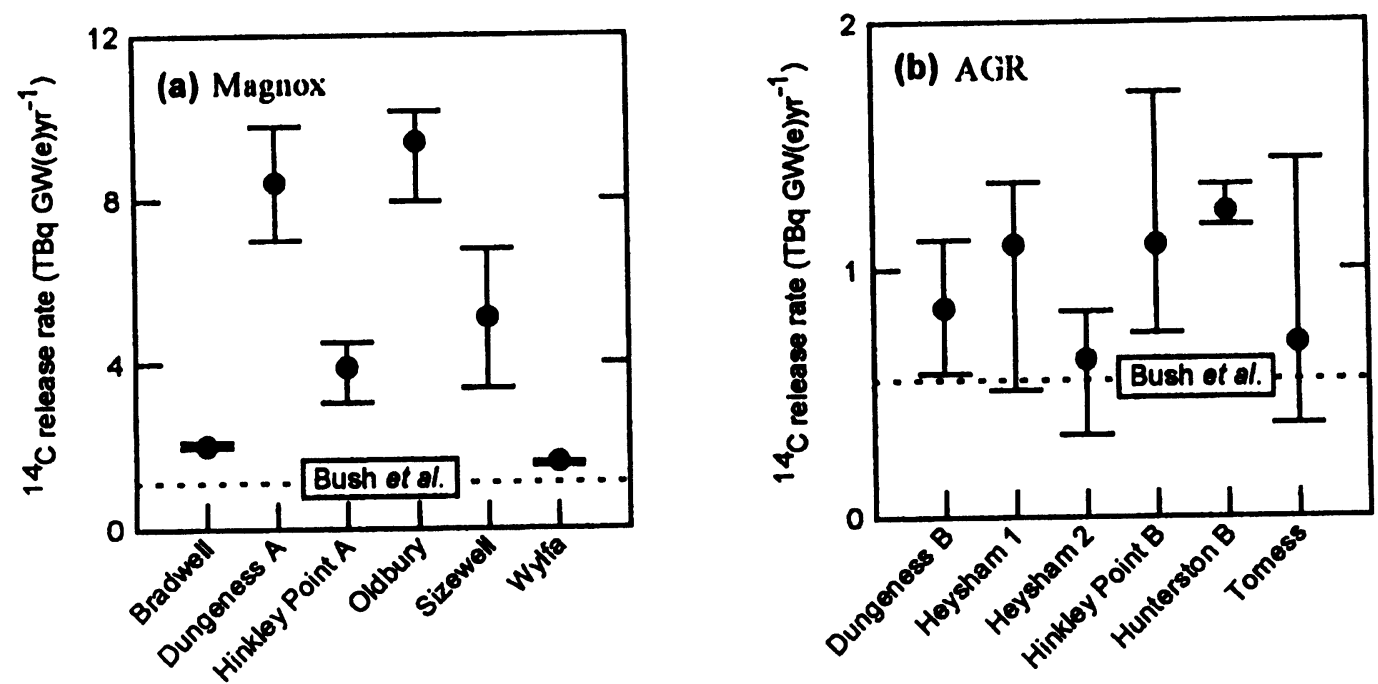

Fig. 2. Average and range of values obtained for ${ }^{14} \mathrm{C}$ release rates from (a) Magnox reactors and (b) AGRs, based on reported discharges

TABLE 3a. ${ }^{14} \mathrm{C}$ Release Rates (TBq GW(e) $\left.\mathrm{a}^{-1}\right)$ from Magnox Reactors, Based on Reported Discharges

\begin{tabular}{lll}
\hline Site & Period & Release rate \\
\hline Bradwell & $1993-1995$ & 2.0 \\
Dungeness A & $1994-1995$ & 8.4 \\
Hinkley Point A & $1992-1995$ & 3.9 \\
Oldbury & $1992-1995$ & 9.4 \\
Sizewell & $1994-1995$ & 5.1 \\
Wylfa & $1990-1995$ & 1.6 \\
Average & & 5.1 \\
\hline
\end{tabular}

TABLE 3b. ${ }^{14} \mathrm{C}$ Release Rates (TBq GW(e)a $\mathrm{a}^{-1}$ ) from AGRs, Based on Reported Discharges

\begin{tabular}{lll}
\hline Site & Period & Release rate \\
\hline Dungeness B & $1994-1995$ & 0.84 \\
Heysham 1 & $1992-1995$ & 1.1 \\
Heysham 2 & $1988-1995$ & 0.63 \\
Hinkley Point B & $1992-1995$ & 1.1 \\
Hunterston B & $1990-1995$ & 1.23 \\
Torness & $1990-1995$ & 0.70 \\
Average & & $\mathbf{0 . 9 3}$ \\
\hline
\end{tabular}

sented in Figure 3 suggest that a total of $531 \mathrm{TBq}$ of ${ }^{14} \mathrm{C}$ have been released up to the end of 1995 , $479 \mathrm{TBq}$ from Magnox reactors and $52 \mathrm{TBq}$ from AGRs.

The best estimates of ${ }^{14} \mathrm{C}$ production and release from Magnox reactors and AGRs are summarized in Table 4. Although the release rates are based on the recent data presented in this paper, the production figures are still based on the estimates of Bush, White and Smith (1984). However, because the ${ }^{14} \mathrm{C}$ discharges appear to be significantly underestimated by the calculations of Bush, White and Smith (1984), the production estimates may also now need revising. 


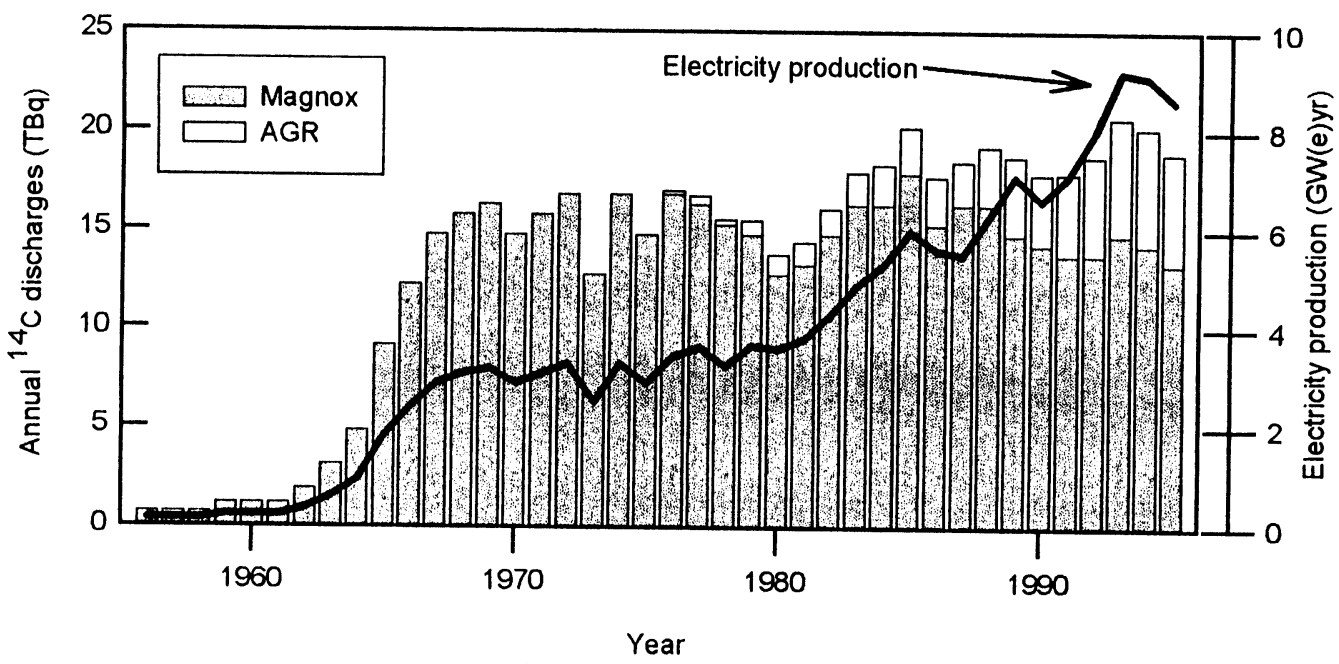

Fig. 3. Estimated annual ${ }^{14} \mathrm{C}$ discharges from UK graphite-moderated reactors

TABLE 4. Estimated ${ }^{14} \mathrm{C}$ Production and Release From UK Magnox Reactors and AGRs up to 1995 (TBq)

\begin{tabular}{lccc}
\hline Reactor type & $\begin{array}{c}\text { Electricity production } \\
(\mathrm{GW}(\mathrm{e}) \mathrm{a})\end{array}$ & $\begin{array}{c}{ }^{14} \mathrm{C} \text { production* } \\
(\mathrm{TBq})\end{array}$ & $\begin{array}{c}{ }^{14} \mathrm{C} \text { release } \dagger \\
(\mathrm{TBq})\end{array}$ \\
\hline Magnox & 94 & 1316 & 479 \\
AGR & 56 & 448 & 52 \\
Total & 150 & 1764 & 531 \\
\hline
\end{tabular}

"Based on ${ }^{14} \mathrm{C}$ production estimates of Bush, White and Smith (1984)

†Based on revised ${ }^{14} \mathrm{C}$ release rates presented in this paper

\section{Sellafield}

The Sellafield complex, situated on the Cumbrian coast in the northwest of England and operated by British Nuclear Fuels plc, contains a wide variety of operations and facilities: fuel element storage and decanning, Magnox and oxide fuel reprocessing plants and the Calder Hall nuclear power station. The vast majority of the ${ }^{14} \mathrm{C}$ discharges from the site, however, result from the nuclear fuel reprocessing operations. The temporal record of these discharges is presented in Figure 4. Atmospheric discharges of ${ }^{14} \mathrm{C}$ have been based on direct monitoring of known sources since 1978; discharges prior to that date have been derived indirectly from ${ }^{14} \mathrm{C}$ measurements of tree rings (Gray, Jones and Smith 1995). The historical record of ${ }^{14} \mathrm{C}$ discharges through the pipeline to the Irish Sea is largely incomplete, although the best available published estimates have been reproduced here (Begg et al. 1992; BNFL 1996).

An estimated total of $388 \mathrm{TBq}$ of ${ }^{14} \mathrm{C}$ has been discharged from Sellafield since the start of operations in 1951 up to the end of 1995. Maximum discharge rates of between 20 and $30 \mathrm{TBq} \mathrm{a}^{-1}$ occurred in the 1970s. Historically, the bulk of the ${ }^{14} \mathrm{C}$ effluent has been released to the atmosphere (335 TBq), although the diversion of ${ }^{14} \mathrm{C}$ effluent from the aerial to the liquid waste stream, which commenced in 1994, means that discharges to the marine environment now exceed atmospheric discharges. 


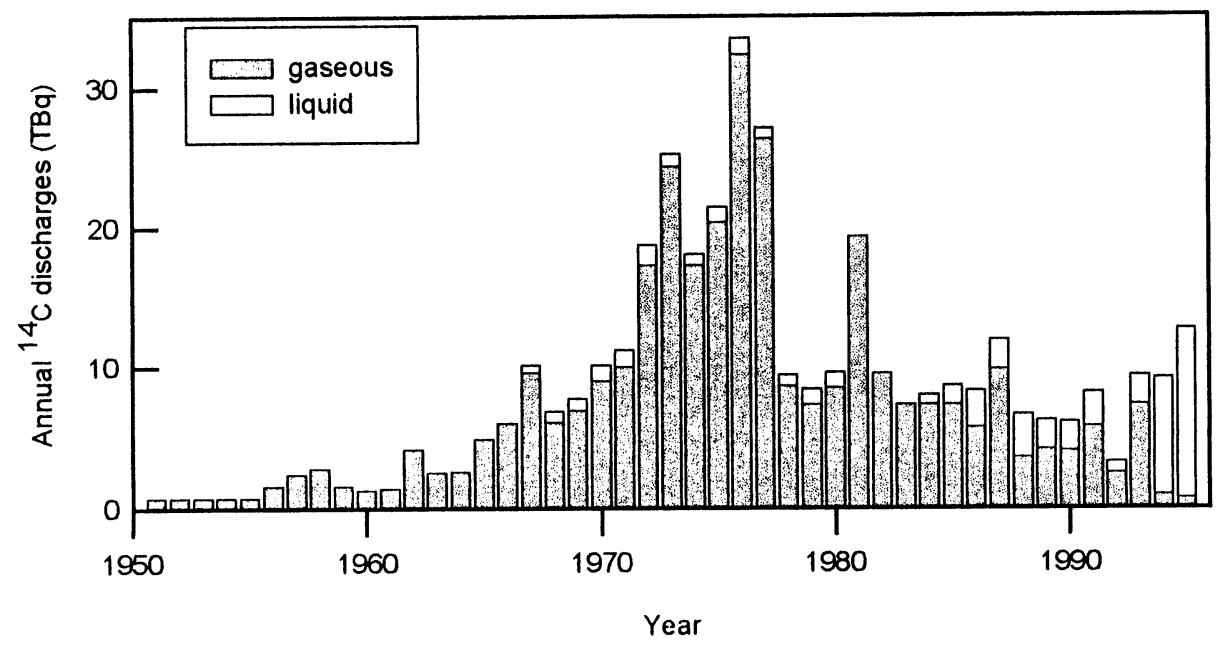

Fig. 4. Annual ${ }^{14} \mathrm{C}$ discharges from Sellafield

\section{Amersham International plc}

Amersham International plc carries out process operations on $\mathrm{Ba}^{14} \mathrm{CO}_{3}$ produced by neutron irradiation of aluminum nitride. Liquid and gaseous discharges from their Cardiff site have been monitored since 1981 and are presented in Figure 5. Since that date a total of $52 \mathrm{TBq}$ of ${ }^{14} \mathrm{C}$ has been released, $34 \mathrm{TBq}$ to the atmosphere and $18 \mathrm{TBq}$ to the hydrosphere.

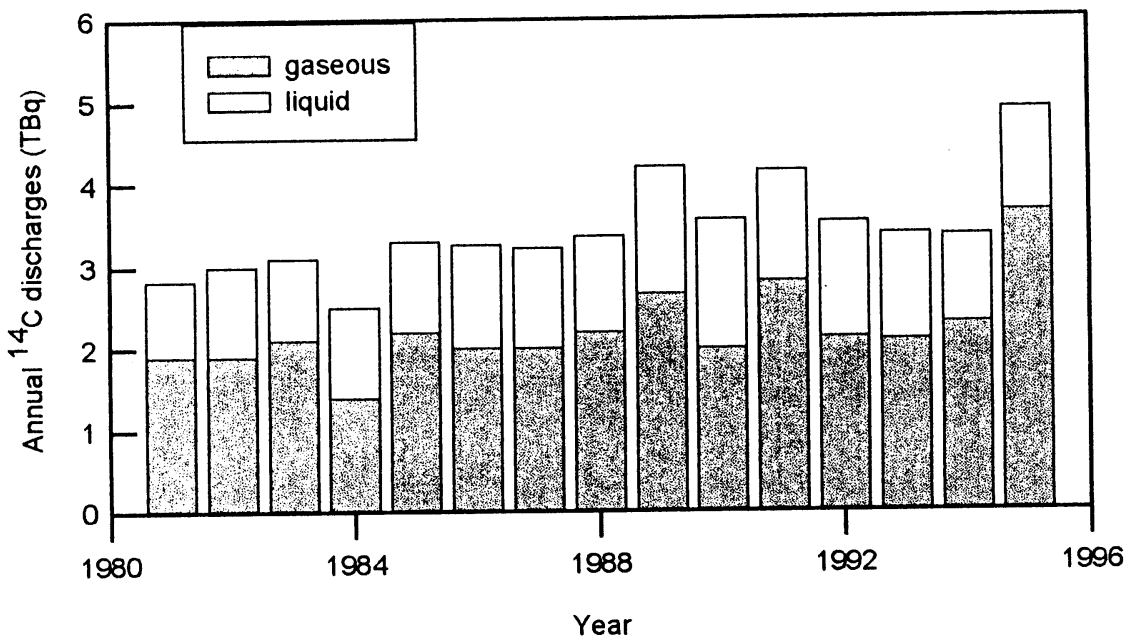

Fig. 5. Annual ${ }^{14} \mathrm{C}$ discharges from Amersham

\section{CONCLUSION}

${ }^{14} \mathrm{C}$ discharges from graphite-moderated reactors have been found to significantly exceed the original theoretically estimated values, particularly for Magnox reactors. This, in turn, raises questions about the accuracy of the ${ }^{14} \mathrm{C}$ production figures for these reactors. New release rate figures, based on reported discharges, of 5.1 and $0.93 \mathrm{TBq} \mathrm{GW}(\mathrm{e}) \mathrm{a}^{-1}$ have been derived for Magnox reactors and 
AGRs, respectively. Using these new figures, cumulative discharges of ${ }^{14} \mathrm{C}$ up to 1995 from reactors have been estimated to be $531 \mathrm{TBq}$. The combination of these reactor discharges and the reported discharges from Sellafield (388 TBq) and Amersham (52 TBq) suggest a total cumulative release of $971 \mathrm{TBq}$ of ${ }^{14} \mathrm{C}$ up to the end of 1995 (Fig. 6).

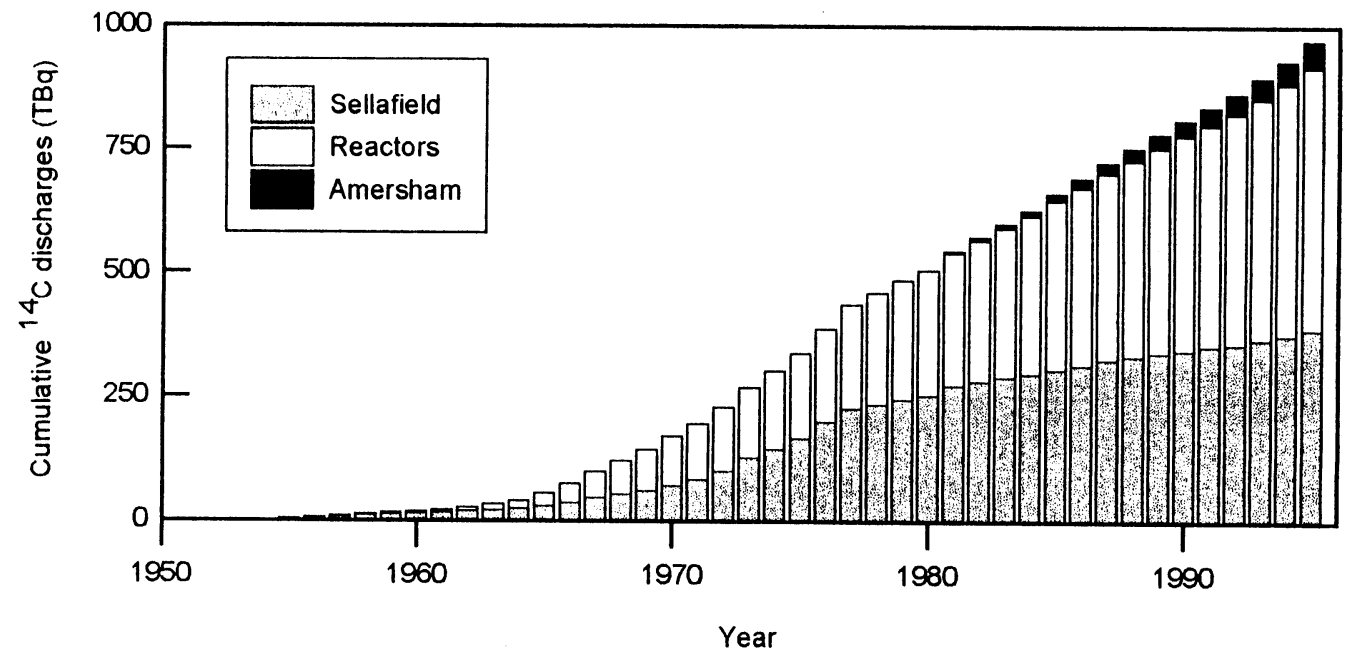

Fig. 6. Cumulative ${ }^{14} \mathrm{C}$ discharges over the period $1951-1995$ from major UK sources

\section{ACKNOWLEDGMENTS}

This work was supported by the Ministry of Agriculture, Fisheries and Food (MAFF project number: 1B093).

\section{REFERENCES}

Begg, F. H., Cook, G. T., Baxter, M. S., Scott, E. M. and McCartney, M. 1992 Anthropogenic radiocarbon in the eastern Irish Sea and Scottish coastal waters. In Long, A. and Kra, R. S., eds., Proceedings of the 14th International ${ }^{14} \mathrm{C}$ Conference. Radiocarbon, 34(3): 707-716.

Bonka, H., 1980 Produktion und Freisetzung von Tritium und Kohlenstoff 14 durch Kernwaffenversuche, TestExplosionen und kerntechnische Anlagen, einschließlich Wiederaufbereitungsanlagen. In Strieve, F. and Kistner, G., eds., Strahlenschutzprobleme im Zusammenhang mit der Verwendung von Tritium und Kohlenstoff-14 und Ihren Verbindungen. STH-Bericht 12/ 80. Neuherberg, Institut für Strahlenhygiene des Bundesgesundheitsamtes: 17-27.

British Nuclear Fuels plc (BNFL) 1996 Annual Report on Radioactive Discharges and Monitoring of the Environment 1995. Volume 1. Report on Discharges and Environmental Monitoring. Warrington, British Nuclear Fuels plc, Health and Safety Directorate: 92 p.

Bush, R. P., Smith, G. M. and White, I. F. 1984 Carbon14 Waste Management. AERE-R10543. Harwell, UK
Atomic Energy Authority.

Davis, W. 1979 Carbon-14 production in nuclear reactors. In Carter, M., Moghissi, A. and Kahn, B., eds., Management of Low Level Radioactive Waste. Vol. 1. Oxford, Pergamon Press: 151-191.

Gray, J., Jones, S. R. and Smith, A. D. 1995 Discharges to the environment from the Sellafield Site, 19511992. Journal of Radiological Protection 15(2): 99_ 131.

Hurst, M. J. and Thomas, D. W. 1992 Radioactive Discharges and Environmental Monitoring at Nuclear Power Stations During 1991. HSD/OSB/R/004. Nuclear Electric plc, Health and Safety Dep't.: 108 p.

International Atomic Energy Agency (IAEA) 1996 Operating Experience with Nuclear Power Stations in Member States in 1994. Vienna, International Atomic Energy Agency.

Joshi, M. L., Ramamirtham, B. and Soman, S. D. 1987 Measurement of ${ }^{14} \mathrm{C}$ emission rates from a pressurized heavy water reactor. Health Physics 52(6): 787-791.

Kelly, G. N., Jones, J. A., Bryant, P. M. and Morley, F. 1975 The Predicted Radiation Exposure of the Popu- 
lation of the European Community Resulting from Discharges of Krypton-85, Tritium, Carbon-14 and Iodine-129 from the Nuclear Power Industry to the Year 2000. DOC V/2576/75. Luxembourg, Commission of the European Communities: $87 \mathrm{p}$.

Killough, G. G. and Rohwer, P. S. 1978 A new look at the dosimetry of ${ }^{14} \mathrm{C}$ released to the atmosphere as carbon dioxide. Health Physics 34: 141-159.

McCartney, M., Baxter, M. S. and Scott, E. M. 1988a Carbon-14 discharges from the nuclear fuel cycle: 1 . Global effects. Journal of Environmental Radioactivity 8: 143-155.

1988b Carbon-14 discharges from the nuclear fuel cycle: 2. Local effects. Journal of Environmental Radioactivity 8: 157-171.

Ministry of Agriculture, Fisheries and Food (MAFF) 1996 Radioactivity in Food and the Environment, 1995. RIFE-1. London, Ministry of Agriculture, Fisheries and Food, Radiological Safety Division: 138 p.

National Council on Radiation Protection (NCRP) 1985 Carbon-14 in the Environment, Recommendations of the National Council on Radiation Protection and Measurements. NCRP Report No. 81. Bethesda, Na- tional Council on Radiation Protection and Measurement: 91 p.

1995 Environment 1994/95. East Kilbride, Scottish Nuclear Limited: 36 p.

Scottish Nuclear Limited 1996 Environment 1995/96. East Kilbride, Scottish Nuclear Limited: $36 \mathrm{p}$.

Thomas, D. W. 1993 Report on Discharges and Environmental Monitoring at Nuclear Power Stations during 1992. NE/NNF/EPP/01, Nuclear Electric plc, Environmental Protection and Planning: $130 \mathrm{p}$.

1994 Report on Discharges and Environmental Monitoring at Nuclear Power Stations during 1993. NE/INF/EPP/03, Nuclear Electric plc, Environmental Protection and Planning: $118 \mathrm{p}$.

1996 Report on Discharges and Environmental Monitoring at Nuclear Power Stations during 1994. NE/INF/EPP/10, Nuclear Electric plc, Environmental Protection and Planning.

United Nations Scientific Committee on the Effects of Atomic Radiation (UNSCEAR) 1993 Sources and Effects of Ionizing Radiation. 1993 Report to the General Assembly. New York, United Nations: 922 p. 